\title{
The Role of Information Sources in Firm R\&D Activities - The Case of German Knowledge Intensive Industries
}

\author{
Viktor Prokop, Jan Stejskal, Petr Hajek \\ University of Pardubice \\ Studentska 95, CZ532 10 Pardubice, Czech Republic \\ E-mail.viktor.prokop@upce.cz; jan.stejskal@upce.cz; petr.hajek@upce.cz \\ cross $^{\text {ref }}$ http://dx.doi.org/10.5755/j01.ee.30.3.20942
}

\begin{abstract}
$R \& D$ activities affect the ability to create innovation for every firm. Many studies have shown that $R \& D$ activities are influenced by a number of determinants and the environment ( $R \& D$ milieu) in which individual economic entities exist. Due to the nature of firms' production, it is important to note that not every firm needs the same amount of information and knowledge. This study will also affect the efficiency of the use of information sources in $R \& D$ activities. In practice, it is necessary to know the dependence of companies and their $R \& D$ activities on the available information sources so that public policy makers can better target public policy and possible financial support schemes (grant schemes), because, the one sizefits all principle cannot be assumed. Therefore, the aim of this paper is to analyze the role of information resources in the knowledge intensive industries in the largest EU economy in terms of GDP, i.e. Germany. For the analysis, Eurostat CIS data and own regression model were used. The results show that the knowledge environment has a major impact on the development of $R \& D$ in the German knowledge intensive firms. German companies sourced information from the market (especially clients and customers), and all firms acquired information and knowledge from collaborating with universities. The biggest impetus for the realization of $R \& D$ activities is for firms to focus on markets outside the $E U$.
\end{abstract}

Keywords: Information Sources; Knowledge; Knowledge Intensive Industry; Germany.

\section{Introduction}

In a closed innovation model, innovation activities were determined by private investment in $\mathrm{R} \& \mathrm{D}$, the capabilities and creativity of own employees, or the ownership of a major production factor (e.g. specific technology) that is not available to any competitor in the market (Almirall \& Casadesus-Masanell, 2010; Littunen \& Rissanen, 2015). Many studies have shown that a company enclosed in "its own innovation environment" does not have the opportunity to get stimulus from the surrounding businesses (often an innovative environment), does not have the ability to benefit from spill over effects and value added, for example through cooperation (Herzog \& Leker, 2010). There has been a paradigm shift to the open innovation model. This model was promoted mainly by Chesbrough (2003). By understanding and using this concept the barriers were barred. These barriers were mostly built by the firm's management and own enclosed strategy. The new innovation model helped in the redefinition of the whole environment in which innovations are emerging - the environment that integrates a wide range of subjects from the private, public or knowledge sphere (Gassmann, 2006). A company moving in this environment must define new relationships and ties in its daily interactions and create a latent or intentional network (Hippel and Krogh, 2003). Depending on the subjects involved and on network basis, it is possible to speak of a knowledge-based network (Monferrer, Blesa \& Ripolles, 2015), cooperation-based network (West \& Bogers, 2014) or business network (La Rocca \& Snehota, 2014). Various studies have shown that the active participation in such networks brings benefits to the company (increasing its productivity, performance and efficiency in the use of production factors; Fuller, Hutter, Hautz \& Matzler, 2014). Similarly, unplanned non-market effects in the form of spill-over effects that bring changes (innovations) in different internal processes of companies, as well as stimuli and impulses for the public sector, and new knowledge or cooperative platforms for knowledge-based organizations, are also emerging (van der Duin, Heger \& Schlesinger, 2014).

The composition or determinants of such environment are the subject of continuous scientific research. Many of mentioned studies concluded that information sources are the important part of the R\&D environment. Information from these sources is transformed into knowledge in the knowledge environment and it is used as input factor in the knowledgebased R\&D production processes in firms. Intezari and Pauleen (2012) agree that information sources, together with experience and previous knowledge (embedded in the firm or the knowledge environment), are sources of knowledge. The above mentioned (and number of other) studies were mostly aimed to analyze the influences of the mentioned determinants on firms' outputs, such as innovations or patents. However, there is a lack of studies which analyze the specific impacts of the various determinants (mostly information sources) of the innovation environment on the knowledge and innovation activities of knowledge intensive firms. To fill the gap, we aim to analyze the determinants of these processes - influences of information sources and other R\&D determinants on firms' R\&D activities. Specifically, our objective is to investigate the role of internal and external R\&D processes, acquisition of knowledge and training for 
innovative activities as outputs of our analyses to explore the conditions and effects occurring within the knowledge intensive environment. For this analysis, we used Eurostat CIS data from 2010-2012 and employed a logistic regression model.

This paper is organized as follows. First, theoretical background is provided on the role of information sources and knowledge management in R\&D performance of the firms. Second, research methodology and underlying data are described. The next section provides the results of logistic regression models. The final section concludes this paper and discusses the results and political implications.

\section{Theoretical Background}

It has already been mentioned earlier that an open innovation model perceives sources of knowledge as a key determinant of firm's innovation capability (Grant, 1996; West \& Gallagher, 2006 or Caloghirou, Kastelli \& Tsakanikas, 2004). In the open innovation model, it is primarily about the external sources of information provided by entities firms cooperates or trades with (almost it is any contact between the firm and the environment - the firm may play the role of a supplier, a customer, a cooperating partner, a dominant player on the market, a member of an association, a member of an institutionalized business network or industrial cluster, etc.) (Laursen and Salter, 2006). The firm most often receives information from suppliers, customers, competitors, public sector organizations or universities, research centers and conferences, publication etc. (Von Hippel, 1986; Laursen \& Salter, 2006).

On the other hand, by adopting the paradigm of an open innovation model, the original closed innovation system in firms cannot be rejected (Chesbrough, 2004). This approach would be considered as a mistake from many scholars' points of view. It must be perceived that the internal and external sources of knowledge are interconnected, the appropriate setting of the internal research (or the creation and use of knowledge) undermines the efficiency of the external source (Elmquist, Fredberg \& Ollila, 2009). Many studies confirm that internal and external knowledge is complementary (Menon \& Pfeffer, 2003; Cassiman, Veugelers, 2006; Lokshin, Belderbos, \& Carree, 2008). It should be remembered that the individual firms' innovation models are implemented in practice gradually and are dependent on the firm's life cycle. Open innovation has become an important competitive advantage in today's globalized economies (Reed, Storrud-Barnes \& Jessup, 2012). Indeed, international trading firms are constantly looking for sources of competitive advantage, and an open concept of innovation that brings them the opportunity to accelerate their innovation processes significantly, cut costs in research, development and innovation processes. This is confirmed by many studies, but also by firms (overview you can see in Gomez, Salazar \& Vargas, 2016). But a new problem is the so-called ,information comprehension“ and transformation into knowledge or workforce competences, respectively. The publication of new information and knowledge and barriers elimination is accelerated by ICT. A range of information is today available in maximum quantity and quality online and mostly free of charge. Therefore, the availability of codified knowledge is not a problem. The current problem is the acquisition of tacit knowledge and its transformation into a commercially viable result (Fores \& Camison, 2016).

It is clear that internal and external information (knowledge) has a major impact on the ability to innovate products and services (Gomez, Salazar and Vargas, 2016). However, it is not only information (knowledge) that becomes an integral part of the final product, but also information or knowledge about customers (or from customers), behavior of firms and other economic entities in markets etc. increase their importance (Ozkaya, Droge, Hult, Calantone \& Ozkaya, 2015). Firms using the concept of open innovation must use information from different sources to increase their internal production efficiency. This is particularly influenced by process, organizational or marketing innovations. Each of them needs a different source and kind of information (Poot, Faems \& Vanhaverbeke, 2014). It is possible to find only a small number of quality studies that deal with the influence of different sources of knowledge, the effectiveness of their use for the needs of internal innovation processes.

Gomez, Salazar and Vargas (2016) studied the sources of information as determinants of product and process innovation. They analyzed Spanish manufacturing firms and the extent to which they use internal and external sources of information (customers, suppliers, competitors, consultants and universities) to generate product and process innovation. Their results show that, although internal sources are influential, external sources of information are key to achieve innovation performance. To generate process innovation, firms mainly rely on suppliers while, to generate product innovation, the main contribution come from customers. The potential simultaneity between product and process innovation is also taken into consideration by Gomez, Salazar and Vargas (2016). They found that the generation of both types of innovation is not independent. Amara and Landry (2005) analyzed the Canadian innovation using survey data from the manufacturing sector. The study considered the impact of four categories of sources of information that firms use to develop or improve their products or manufacturing processes: internal sources, market sources, research sources, and generally available sources of information. The study concluded that firms have to use a larger variety of sources of information, and more especially, to use a much larger variety of research sources to develop or improve their products or processes. Zieba, Bolisani, Paiola and Scarso (2017) analyzed knowledge that can lead to the introduction of service innovations in Italian and Polish KIBS firms. They concluded that KIBS firms follow various approaches to acquire knowledge for innovation: some companies adopt a passive behaviour and while others an active one.

Hervas-Oliver, Sempere-Ripoll and Boronat-Moll (2014) analyzed the process innovation strategy in Spanish SMEs. Their results suggested that RandD efforts are not positively related to the production process performance, but that the latter is improved by the synchronous coadoption of organizational and technological innovation. Innovative SMEs rely on the acquisition of external knowledge sources to complement the lack of inhouse knowledge or insufficient in-house $R \& D$ results. 
Absolutely specific group of firms that use knowledge in their production process are the knowledge- or technology-intensive industries. They are significant because these firms are an essential pillar of the advanced industrial regions (Heidenreich, 2009). Low- and mediumtechnology industries still make up the largest part of the manufacturing industries in OECD countries and that their preponderance is falling at a very slow rate (Santamaria, Nieto \& Barge-Gil, 2009). A substantial body of research in management and related public policy fields concludes that recent decades saw greater dynamic competition throughout the knowledge or technology-intensive industries, with widespread steady increase in knowledge intensive industry and business performance instability as key implications. Positive network effects, feedback mechanisms, and increasing returns to scale from market leadership are especially important in the knowledge intensive industries (Vaaler \& McNamara, 2010).

Currently, Germany represents the largest economy in the European Union in terms of GDP and one of the most competitive economies in the world (WEF, 2017). Germany was ranked fifth in The Global Competitiveness Index 2017-2018 Rankings carried out by World Economic Forum. According to Germany: STI Outlook 2014 Country Profile (2014), it is leading player in global innovation and science. This is due to the fact that stimulus for investment and a good climate for innovation and private-sector investment are of crucial significance for German government. Therefore, Germany belongs to the group of Innovation Leaders within European Union measured by European Commissions' European Innovation Scoreboard (EIS). Niebuhr and Peters (2012) analysed relation between labour diversity and firm's innovation in Germany; Robin and Schubert (2013) analysed the impact of cooperation with public research on firms' product and process innovations in France and Germany; Czarnitzki and LopesBento (2014) analysed the effect of European and national funding on innovation input and output at the firm level in Germany. However, there is a lack of studies analysing the role of Information Sources in firm R\&D activities, especially within Knowledge Intensive Industries in Germany.

Therefore, following the previous parts, the aim of this paper is to analyze influences of different information sources and R\&D determinants (for details please see the proposal of the research model in figure 1) on firms' $R \& D$ activities in the German knowledge and technology intensive industries and provide benchmark for those industries and for other EU countries.

\section{Data and Methodology}

Based on the above studies, we assume that there is a previously established and evidenced dependency between our selected variables (information sources and other R\&D determinants) and corporate $R \& D$ activities in firms. These activities (altogether constitute the knowledge and innovative environment) should lead to the creation of synergies and production of corporate innovations (see Figure 1). We consider it important to investigate which of these variables influence the R\&D outcomes and to what extent. We would like to determine whether all variables are equally significant and have the same impact on $R \& D$ activities of the firms; which of them should be targeted by the firms to increase their absorption capability and innovation production. The selected variables are the integral parts of an innovative environment in all regions and countries.

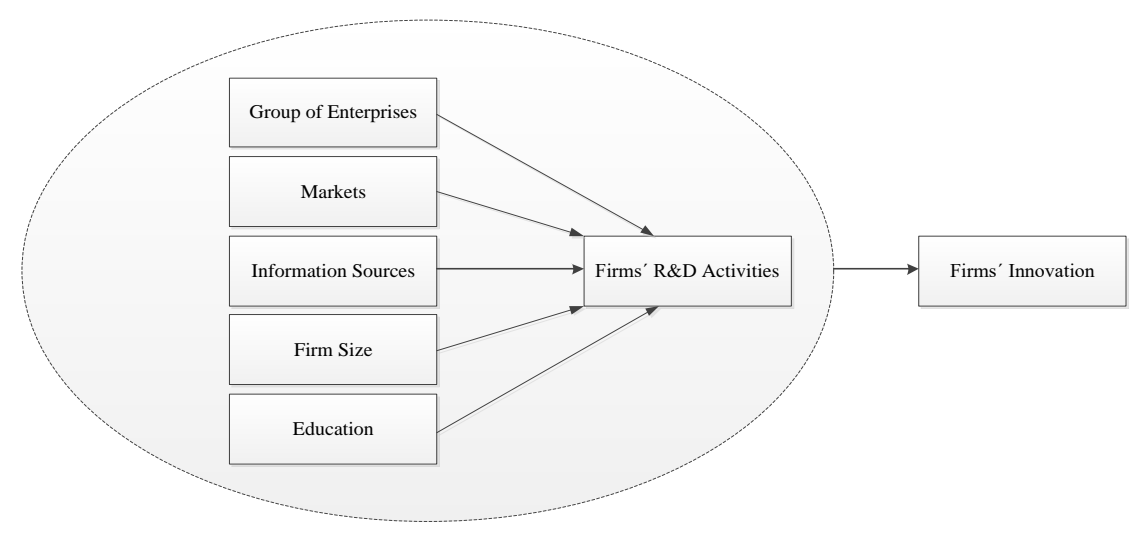

Figure 1. Proposal of research model

As output variables ( $R \& D$ activities) we selected:

- In-house R\&D that enhances the probability to bring new products (innovations) ahead of competitors and allow firms to expand firm's absorptive capacity, by allowing to better monitor, interpret and absorb scientific knowledge that is conducted externally to firms (Fabrizio, 2009; Higon, 2016);

- External R\&D which support firms' productivity (Lokshin et al., 2008) and lead to faster and cheaper innovation processes resulting in the creation of knowledge spillover effects (Vega-Jurado et al., 2009; Prokop \& Stejskal, 2017);

- Acquisition of knowledge that ensure knowledge flows to the firms, saves $R \& D$ costs, secures access to technical services and requires less absorptive capacity than does R\&D cooperation (Adams \& Marcu, 2004; Arvanitis et al., 2015);

- Training for innovative activities, which deepens on firms' absorptive capacity, innovation capability and extends the knowledge base of employees 
(Caloghirou, Kastelli \& Tsakanikas, 2004; Mateut, 2018).

Input variables have been grouped according to their character into five groups:

- Whether the enterprise belongs to the group of enterprises (e.g. holding member), because firms' from enterprises groups are able to draw on resources from within their wider groups and might, therefore, not need to seek as many resources externally. It helps them to reduce costs. Group firms may also be better informed of the capabilities of potential partners due to knowledge pooling and the activities of other members of their group and can benefit from knowledge spillovers (Tether, 2002);

- The markets in which the enterprises are oriented towards can lead to better innovation capability in the organizations which in turn can lead to better organizational performance (Migdadi et al., 2017). Businesses with a strong market orientation are best situated for new product success, no matter what the business environment is (Lukas \& Ferrell, 2000);

- What types of information sources it uses in R\&D activities. Littunen and Rissanen (2015) state that various kinds of information sources (also together with networking) influence organizations' performance and, therefore, novel innovations (both product and service) are closely associated with different information sources;

- Firm size (expressed by turnover) that is significantly associated with firms' innovation and export performance (Hwang et al., 2015) and has a direct positive effect on incremental innovation performance and on internal knowledge creation capability (Fores \& Camison, 2016);

- What level of education employees have. Employees' education boosts employees' creativity (generation of novel and useful ideas) which is the micro-foundation of firm innovation (Liu et al., 2017).

Specifically, the following input variables were selected:

- Group of Enterprises: Enterprise as part of an enterprise group (GP);

- Markets: National (MARNAT), Other European Union or associated countries (MAREUR) and all other countries (MAROTH);

- Information sources: Within enterprise or enterprise group (SENTG), Universities or other higher education institutions (SUNI), Suppliers of equipment, materials, components, or software (SSUP), Government, public or private research institutes (SGMT), Clients or customers from the private sector (SCLPR), Conferences, trade fairs, exhibitions (SCON), Clients or customers from the public sector (SCLPU), Scientific journals and trade/technical publications (SJOU), Competitors or other enterprises in industry (SCOM), Professional and industry associations (SPRO) and Consultants and commercial labs (SINS);

- Firms Size: Enterprise's total turnover for 2012 (TURN);

- Education: \% of employees with tertiary education (EMPUD).

As a data source, we collected and pre-processed data from the Community Innovation Survey (CIS) 2010-2012. CIS is harmonized questionnaire created for all EU Member States by Eurostat and combines stratified random sampling with exhaustive surveys. We analyzed 1949 enterprises, only enterprises with more than 10 employees (response rate greater than $60 \%$ ). Selected knowledge and technology intensive (high or medium tech) industries that were included in our analyses are listed in Table 1. Only four largest knowledge and technology intensive industries in Germany were included.

Table 1

Selected Industries for the Analysis

\begin{tabular}{|l|c|c|}
\hline \multicolumn{1}{|c|}{ Industry } & Number of enterprises & NACE categories \\
\hline Electrical & 474 & $26-27$ \\
\hline Chemical and Pharmaceutical & 473 & $19-22$ \\
\hline Metal & 465 & $24-25$ \\
\hline Machines and Equipment & 537 & 28,33 \\
\hline Total & 1949 & \\
\hline
\end{tabular}

Source: own processing

According to CIS dataset, all input and output variables were binary. Therefore, in agreement with previous related studies (e.g. see Archer \& Lemeshow, 2006; Coad \& Rao, 2008; Schneider \& Spieth, 2013), our empirical analyses were performed by using the binary logistic regression models. Logistic regression is a popular statistical technique in which the probability of a dichotomous outcome (e.g. R\&D activity) is related to a set of explanatory variables (e.g. different information sources). The logistic regression model is specified as follows (Neupane et al., 2002):

$\ln \left[P_{i} /\left(1-P_{i}\right)\right]=\beta_{0}+\beta_{1} \times X_{1 i}+\beta_{2} \times X_{2 i}+\ldots+\beta_{n} \times X_{n i}$, (1)

where subscript $i$ denotes the $i$-th observation in the sample, $\mathrm{P}$ is the probability of the outcome, $\beta_{0}$ is the intercept term, and $\beta_{1}, \beta_{2}, \ldots \beta_{n}$ are the coefficients associated with each explanatory variable $X_{1}, X_{2}, \ldots, X_{k}$. A positive coefficient means that the $\log$ of odds increases as the corresponding independent variable increases. However, it is possible to interpret the coefficients in terms of odds $[P /(1-P)]$ or probability $(P)$ of the outcome by observing the relationship between $P,[P /(1-P)]$ and $\ln [P$ $/(1-P)]$. It can be shown that $[P /(1-P)]$ is a monotonically increasing function of $P$ and $\ln [P /(1-P)]$ is a monotonically increasing function of $[P /(1-P)]$. Consequently, if the $\log$ of odds $\ln [P /(1-P)]$ is positively (negatively) related to an independent variable, both odds $[P$ / $(1-P)]$ and probability $(P)$ of the outcome are also positively (negatively) related to that variable. The only difference is that this relationship is linear for the log of odds and nonlinear for odds and probability of the outcome. The 
coefficients in the logistic regression are estimated using the maximum likelihood estimation method (for further explanation see Neupane et al., 2002 or Retherford \& Choe, 2011). We tested the collinearity among the independent variables by Variance Inflation Factor (VIF) for each regression model. Multicollinearity was rejected in the models $(\mathrm{VIF}<5)$.

\section{Empirical Results}

In the following part, we show the results of four logistic regression models analyzing the influences of different information sources and $R \& D$ determinants on firms' R\&D activities in the German knowledge and technology intensive industries. Each model was created to analyze different output variable (In-house R\&D; External R\&D; Acquisition of knowledge; Training for innovative activities).

Table 2 shows the information sources and other R\&D determinants that significantly influenced firms' research activities in the German technology intensive industries. The results pointed out that firms' internal and external $\mathrm{R} \& \mathrm{D}$, acquisition of knowledge and training for innovative activities are strongly dependent on the markets where firms are located and the firms' size (TURN, significant in all cases). Non-European markets (MAROTH) influenced selected research activities more than national and European markets. For example, these are American, Asian or Indian markets with a strong global influence. Moreover, selecting wrong markets (e.g. MARNAT in Table 2) could lead to negative results. Therefore, it is necessary to analyze influences of different information sources and R\&D determinants deeply (see below).

Internal information sources (specifically within enterprises or enterprise groups) represented one of the most significant factors influencing firms' R\&D activities. These results are in agreement with other previous studies that pointed out the importance of internal information sources and information (knowledge) flows from both the enterprise itself and its enterprise group (Criscuolo et al., 2010). Gomez et al. (2016) stated the importance of the different sources of information used by firms while the internal sources of information were the most important (78\% of cases). Internal information sources and knowledge sharing can synthesize individually held know-how and help construct a deeper and more refined understanding of its existing knowledge. Therefore, a firm with a broad knowledge base is more likely to achieve innovation (radical) in the presence of internal knowledge sharing rather than market knowledge acquisition (Zander \& Solvell, 2000; Tsai, 2001; Zhou \& Li, 2012).

On the other hand, Dahlander et al. (2016) also added that too much attention paid to internal information sources may limit the number and range of novel knowledge and ideas introduced, as well as novel R\&D. Therefore, firms focusing on the internal needs and sources need to figure out how to allocate their attention to the variety of external information sources. Ideas sourced externally will have relevance for the firm. The creation of competitive advantages rests in relational tools that is the way of doing business, both in the internal and external environments of firms (Amara \& Landry, 2005).

Table 2

Influence of Information Sources and R\&D Determinants on Firms'

\begin{tabular}{|c|c|c|c|c|c|c|c|c|}
\hline \multirow[t]{2}{*}{ Variables } & \multicolumn{2}{|c|}{ In-house R\&D } & \multicolumn{2}{|c|}{ External R\&D } & \multicolumn{2}{|c|}{ Acquisition of knowledge } & \multicolumn{2}{|c|}{$\begin{array}{c}\text { Training for innovative } \\
\text { activities }\end{array}$} \\
\hline & $p$-value & $\beta(\exp \beta)$ & $p$-value & $\beta(\exp \beta)$ & $p$-value & $\beta(\exp \beta)$ & $p$-value & $\beta(\exp \beta)$ \\
\hline GP & .374 & $.161(1.174)$ & $.000 * * *$ & $.575(1.776)$ & $.013^{* *}$ & $.399(1.490)$ & .908 & $.017(1.017)$ \\
\hline MARNAT & .568 & $-.176(.839)$ & $.012 * *$ & $-.711(.491)$ & .815 & $.072(1.074)$ & .606 & $.127(1.135)$ \\
\hline MAREUR & .119 & $.351(1.420)$ & $.075^{*}$ & $.406(1.501)$ & $.063^{*}$ & $-.457(.633)$ & .389 & $-.169(.845)$ \\
\hline MAROTH & $.001^{* * *} *$ & $.687(1.987)$ & $.004 * * *$ & $.555(1.742)$ & $.006 * * *$ & $.616(1.851)$ & $.060 *$ & $.329(1.389)$ \\
\hline SENTG & $.000^{* * * *}$ & $.741(2.097)$ & $.026 * *$ & $.179(1.196)$ & $.033^{* *}$ & $.190(1.209)$ & $.000 * * *$ & $.501(1.650)$ \\
\hline SSUP & .525 & $-.063(.939)$ & .755 & $.028(1.028)$ & .377 & $.082(1.086)$ & $.000 * * *$ & $.340(1.405)$ \\
\hline SCLPR & $.004 * * *$ & $.221(1.248)$ & $.002 * * *$ & $.215(1.240)$ & $.040^{* *}$ & $.157(1.170)$ & $.006 * * *$ & $.173(1.189)$ \\
\hline SCLPU & $.077 *$ & $.182(1.200)$ & .480 & $.056(1.058)$ & .150 & $.117(1.124)$ & .994 & $-.001(.999)$ \\
\hline SCOM & .408 & $-.087(.916)$ & .455 & $-.065(.937)$ & .598 & $-.048(.953)$ & $.012 * *$ & $-.210(.811)$ \\
\hline SINS & .182 & $-.149(.862)$ & $.019 * *$ & $.216(1.241)$ & .270 & $.106(1.112)$ & .870 & $.015(1.015)$ \\
\hline SUNI & $.000 * * *$ & $.774(2.167)$ & $.000 * * *$ & $.715(2.043)$ & $.000 * * *$ & $.313(1.367)$ & $.027 * *$ & $.162(1.176)$ \\
\hline SGMT & .733 & $-.071(.931)$ & $.089 *$ & $.262(1.299)$ & .352 & $.149(1.160)$ & .915 & $-.017(.983)$ \\
\hline SCON & .272 & $.126(1.134)$ & .167 & $.135(1.145)$ & $.078^{*}$ & $.181(1.199)$ & $.009 * * *$ & $.238(1.269)$ \\
\hline SJOU & $.000 * * *$ & $.586(1.796)$ & .666 & $-.046(.955)$ & .779 & $.031(1.032)$ & .145 & $.144(1.155)$ \\
\hline SPRO & $.002 * * *$ & $-.400(.670)$ & $.042 * *$ & $-.213(.808)$ & .966 & $.005(1.005)$ & $.009 * * *$ & $.267(1.306)$ \\
\hline TURN & $.049 * *$ & $.000(1.000)$ & $.018 * *$ & $.000(1.000)$ & $.000 * * *$ & $.000(1.000)$ & $.054 *$ & $.000(1.000)$ \\
\hline EMPUD & $.000 * * *$ & $.398(1.488)$ & $.000 * * *$ & $.287(1.333)$ & .277 & $.066(1.069)$ & $.055^{*}$ & $.100(1.105)$ \\
\hline Nagelkerke $R^{2}$ & .646 & & .436 & & .286 & & .417 & \\
\hline Cox \& Snell $R^{2}$ & .477 & & .311 & & .182 & & .312 & \\
\hline -2 Log likelihood & 1003.077 & & 1258.565 & & 1171.203 & & 1426.337 & \\
\hline Accuracy (\%) & 85.3 & & 77.8 & & 81.2 & & 73.6 & \\
\hline
\end{tabular}

Legend: * statistically significant at $p=.10$, ** at $p=.05$ and $* * *$ at $p=.01$.

Source: own processing

Therefore, our results show that German firms sourced information from other sources (for example conferences, journals, cooperation with unanalyzed entities etc.). Market information sources, especially clients and customers, represented other significant sources influencing all $R \& D$ activities (see Table 2). Verhees and Meulenberg (2004) show that orientation on market sources (specifically customers) has a positive influence on firms' $R \& D$ performance and product innovations. These findings are based on the main idea of open innovation theory which 
proved that valuable ideas can emanate from inside or outside the company and can reach the market from inside or outside the company as well (Chesbrough et al., 2006). Therefore, using information sources from clients or customers from the private sector significantly influenced firms' research activities. Von Stamm (2004) also pointed the key role of clients and customers' needs and obtaining information from these entities (see also the principles of Lead-User theory; e.g. Franke et al., 2006). Generally, firms operating in technology intensive industries face competitive pressures to build a larger and broader portfolio (e.g. of related products) in order to gain and maintain their competitive advantage, which drive them to rely on outside actors in order to organize some R\&D services and activities (Martinez-Noya et al., 2012).

Universities as information source influenced all firms' research activities. Laursen and Salter (2004) proved the link between universities, and industrial $R \& D$ and innovation. They suggested that firms that adopt open search strategies (based on open innovation principles) and invest in R\&D are more likely than other firms to draw from universities. Therefore, firms' size expressed by turnover (TURN), information sources from universities (SUNI) and employees' education (EMPUD) play a key role in the process of firms' $R \& D$ in the German technology intensive industries.

Conferences, trade fairs and exhibitions represent other information sources and events where firms profiting from voluntary information and knowledge spillovers and where firms can create new networks and share information (Chesbrough \& Brunswicker, 2014). Specifically in the process of acquisition of knowledge and training for innovative activities. On the other hand, professional and industry associations as information sources influenced firms' research activities negatively in two cases (external and in-house R\&D). Therefore, it is necessary to carefully source information from different entities. Proper finding of information sources could subsequently positively influence firms' research activities, also professional and industry associations (see Table 2).

Participation in the groups of companies (GP) influenced only firms' acquisition of knowledge and external R\&D activities. This participation represents incubator for creating new knowledge within firms and allows information flows and creation of synergies. However, firms' internal R\&D activities were not influenced. German firms are usually open and pro-export oriented. They tend to share their internal know-how and organizational procedures with other entities in suppliercustomer relations. These firms are frequently embedded in economic environment and use the savings and knowledge spillover effects from the cooperation-based networking. Thus, firms are blocking the lock-in effects and losing competitive advantage. They know that radical innovations or technological discontinuities may require new information, institutions and resources (Narula, 2002). And these can get just by openness and willingness to cooperate. There is a specific form of "closed-open" cooperative networking system - global production chains (or systems). In these relatively closed networks, firms and other entities inside can collaborate freely (Henderson et al., 2002).

\section{Conclusions}

Previous studies have shown that the knowledge base is an important part of the $R \& D$ environment in every economy. Both information and knowledge (tacit and codified), but also previous experiences are integral part of this basis. However, the potential of individual workers in companies or knowledge sector organizations (universities and R\&D organizations), which work with information and knowledge, apply them, and deal with their everyday problems, are a necessary part of this $R \& D$ environment. Our study confirms that information resources are important incentives for the development of science and research at different knowledge intensive German firms.

This paper brings a number of benefits through the results. We found out which parts of the knowledge environment have a major impact on the development of R\&D among German knowledge and technology intensive firms. When we analyzed the impact of information sources and $R \& D$ determinants on firms' in-house $R \& D$, we found that German companies had sourced various information sources. Market information sources, especially from clients and customers, represent also significant sources influencing all R\&D activities. Information sources also have an impact on external R\&D. Universities as an information source have influenced the research activities of all analyzed German knowledge intensive firms. This unambiguously proves that companies could build partnerships with universities and obtain valuable information from created reciprocal relationships. The problem of such a partnership may be the obvious dichotomy in the goals, as well as the high degree of bureaucracy and time delay. On the other hand, companies' pressure can help the whole situation, and universities can be reformed faster under this pressure and begin to fulfill new functions and tasks in the current knowledge world.

It has been found that group of companies (holding or business network) also have the opportunity to acquire information and share knowledge within this group. The results show that belonging to the groups of companies influenced only firms' acquisition of knowledge and training for innovative activities. The benefit of such cooperation is the low level of funding, the possibility of technology sharing and clear coordination and support. However, a certain closure (or total lock-in situation) of this business community may be a negative one. The difficult penetration of new impulses and information into this network is also a weakness.

In conclusion, it can be argued that the results of the German knowledge intensive firms provide clear evidence of what information sources are important for the realization of firms' R\&D activities. Companies, as well as public policy makers and supportive public financial donors, can benefit from our results. We should also mention the limitations of our research. We sense that we are working with CIS data that are the result of self-evaluation of individual businesses, the ability to report may be lower in some cases. The perception of individual variables may be different in different countries, so international comparisons have only limited potential. On the other hand, these are official data from the Eurostat and the survey was harmonized and representative for all the studied countries. 
Our results can also be suitable for benchmarking activities. That is how our results can be applied in other countries. Further research should be focused on the possibility of applying the findings in other economies, respectively on the conditions of compatibility or similarity of such an economy to ensure the maximum efficiency of the use of information sources in $R \& D$ activities of the knowledge intensive firms.

\section{Acknowledgments}

This work was supported by a grant provided by the scientific research project of the Czech Sciences Foundation Grant No. 17-11795S.

\section{References}

Adams, J. D., \& Marcu, M. (2004). R\&D sourcing, joint ventures and innovation: A multiple indicators approach, NBER Working Paper No. 10474. Cambridge: NBER. https://doi.org/10.3386/w10474

Almirall, E., \& Casadesus-Masanell, R. (2010). Open versus closed innovation: A model of discovery and divergence, Academy of Management Review, 35(1), 27-47. https://doi.org/10.5465/AMR.2010.45577790

Amara, N., \& Landry, R. (2005). Sources of information as determinants of novelty of innovation in manufacturing firms: Evidence from the 1999 statistics Canada innovation survey, Technovation, 25(3), 245-259. https://doi.org/10.1016/S0166-4972(03)00113-5

Archer, K. J., \& Lemeshow, S. (2006). "Goodness-of-fit test for a logistic regression model fitted using survey sample data," Stata Journal, 6(1), 97-105. https://doi.org/10.1177/1536867X0600600106

Arvanitis, S., Lokshin, B., Mohnen, P., \& Worter, M. (2015). Impact of external knowledge acquisition strategies on innovation: A comparative study based on Dutch and Swiss panel data, Review of Industrial Organization, 46(4), 59382. https://doi.org/10.1007/s11151-015-9450-7

Borradaile, G. J. (2013). Statistics of Earth Science Data: Their Distribution in Time, Space and Orientation, Heidelberg: Springer-Verlag.

Caloghirou, Y., Kastelli, I., \& Tsakanikas, A. (2004). Internal capabilities and external knowledge sources: complements or substitutes for innovative performance? Technovation, 24(1), 29-39. https://doi.org/10.1016/S0166-4972(02)00051-2

Cassiman B., \& Veugelers, R. (2006). In search of complementarity in innovation strategy: Internal RandD and external knowledge acquisition, Management Science, 52(1), 68-82. https://doi.org/10.1287/mnsc.1050.0470

Chesbrough, H. (2003). Open Innovation: The New Imperative for Creating and Profiting from Technology, Boston, MA.: Harvard Business Press.

Chesbrough, H. (2004). Managing open innovation, Research-Technology Management, 47(1), $23-26$. https://doi.org/10.1080/08956308.2004.11671604

Chesbrough, H., \& Brunswicker, S. (2014). A fad or a phenomenon?: The adoption of open innovation practices in large firms, Research-Technology Management, 57(2), 16-25.

Chesbrough, H., Vanhaverbeke, W., \& West, J. (Eds.). (2006). Open Innovation: Researching a New Paradigm, Oxford: Oxford University Press on Demand.

Coad, A., \& Rao, R. (2008). Innovation and firm growth in high-tech sectors: A quantile regression approach, Research Policy, 37(4), 633-648. https://doi.org/10.1016/j.respol.2008.01.003

Criscuolo, C., Haskel, J. E., \& Slaughter, M. J. (2010). "Global engagement and the innovation activities of firms," International Journal of Industrial Organization, 28(2), 191-202. https://doi.org/10.1016/j.ijindorg.2009.07.012

Czarnitzki, D., \& Lopes-Bento, C. (2014). Innovation subsidies: Does the funding source matter for innovation intensity and performance? Empirical evidence from Germany, Industry and Innovation, 21(5), 380-409. https://doi.org/10.1080/ 13662716.2014 .973246

Dahlander, L., O'Mahony, S., \& Gann, D. M. (2016). One foot in, one foot out: how does individuals' external search breadth affect innovation outcomes? Strategic Management Journal, 37(2), 280-302. https://doi.org/10.1002/smj.2342

Elmquist, M., Fredberg, T., \& Ollila, S. 2009. Exploring the field of open innovation, European Journal of Innovation Management, 12(3), 326-345. https://doi.org/10.1108/14601060910974219

Fabrizio, K. R. (2009). Absorptive capacity and the search for innovation, Research Policy, 38(2), $255-267$. https://doi.org/10.1016/j.respol.2008.10.023 
Viktor Prokop, Jan Stejskal, Petr Hajek. The Role of Information Sources in Firm R\&D Activities - The Case of German...

Fores, B., \& Camison, C. (2016). Does incremental and radical innovation performance depend on different types of knowledge accumulation capabilities and organizational size?" Journal of Business Research, 69(2), 831-848. https://doi.org/10.1016/j.jbusres.2015.07.006

Franke, N., Von Hippel, E., \& Schreier, M. (2006). Finding commercially attractive user innovations: A test of lead-user theory, Journal of Product Innovation Management, 23(4), 301-315. https://doi.org/10.1111/j.1540-5885.2006.00203.x

Fuller, J., Hutter, K., Hautz, J., \& Matzler, K. (2014). User roles and contributions in innovation-contest communities, Journal of Management Information Systems, 31(1), 273-308. https://doi.org/10.2753/MIS0742-1222310111

Gassmann, O. (2006). Opening up the innovation process: towards an agenda,. R\&D Management, 36(3), $223-228$. https://doi.org/10.1111/j.1467-9310.2006.00437.x

Gerguri-Rashiti, S., Ramadani, V., Abazi-Alili, H., Dana, L. P., \& Ratten, V. (2017). ICT, innovation and firm performance: the transition economies context, Thunderbird International Business Review, 59(1), 93-102.

Germany: STI Outlook (2014) Country Profile. The Innovation Policy Platform [online]. 2014 [cit. 2018-06-06]. Available at: https://www.innovationpolicyplatform.org/content/germany

Gomez, J., Salazar, I., \& Vargas, P. (2016). Sources of information as determinants of product and process innovation, PloS one, 11(4), https://doi.org/10.1371/journal.pone.0152743

Grant, R. M. (1996). Toward a knowledge-based theory of the firm, Strategic Management Journal, 17(S2), 109-122. https://doi.org/10.1002/smj.4250171110

Grillitsch, M., Todtling, F., \& Hoglinger, C. 201). Variety in knowledge sourcing, geography and innovation: Evidence from the ICT sector in Austria, Papers in Regional Science, 94(1), 25-43.

Heidenreich, M. (2009). Innovation patterns and location of European low-and medium-technology industries, Research Policy, 38 (3), 483-494. https://doi.org/10.1016/j.respol.2008.10.005

Henderson, J., Dicken, P., Hess, M., Coe, N., \& Yeung, H. W. C. (2002). Global production networks and the analysis of economic development. Review of International Political Economy, 9(3), 436-464. https://doi.org/10.1080/ 09692290210150842

Hervas-Oliver, J. L., Sempere-Ripoll, F., \& Boronat-Moll, C. (2014). Process innovation strategy in SMEs, organizational innovation and performance: a misleading debate? Small Business Economics, 43(4), 873-886. https://doi.org/10.100 7/s11187-014-9567-3

Herzog, P., \& Leker, J. (2010). Open and closed innovation-different innovation cultures for different strategies, International Journal of Technology Management, 52(3/4), 322-343. https://doi.org/10.1504/IJTM.2010.035979

Higon, D. A. (2016). In-house versus external basic research and first-to-market innovations, Research Policy, 45(4), 816829. https://doi.org/10.1016/j.respol.2016.01.005

Hippel, E. V., \& Krogh, G. V. (2003). Open source software and the "private-collective innovation model: Issues for organization science," Organization Science, 14(2), 209-223. https://doi.org/10.1287/orsc.14.2.209.14992

Hwang, Y. S., Hwang, M. H., \& Dong, X. (2015). "The relationships among firm size, innovation type, and export performance with regard to time spans," Emerging Markets Finance and Trade, 51(5), 947-962. https://doi.org/10.10 80/1540496X.2015.1061386

Intezari, A., \& Pauleen, D. (2012). "When knowledge is insufficient: Wisdom in a complex world," in Proceedings from AMCIS 2012, paper 4, 1-11

La Rocca, A., \& Snehota, I. (2014). "Relating in business networks: Innovation in practice, Industrial Marketing Management, 43(3), 441-447. https://doi.org/10.1016/j.indmarman.2013.12.012

Laursen K., \& Salter, A. (2006). Open for innovation: the role of openness in explaining innovation performance among U.K. manufacturing firms, Journal of Strategic Management, 27(2), 131-150. https://doi.org/10.1002/smj.507

Laursen, K., \& Salter, A. (2004). Searching high and low: what types of firms use universities as a source of innovation? Research Policy, 33(8), 1201-1215. https://doi.org/10.1016/j.respol.2004.07.004

Littunen, H., \& Rissanen, S. (2015). Information sources and innovation-linked networking: relations to health and social service enterprises' performance in Finland, Innovation and Development, 5(1), 93-111. https://doi.org/10.1080/ 2157930X.2014.994261

Liu, D., Gong, Y., Zhou, J., \&d Huang, J. C. (2017). Human resource systems, employee creativity, and firm innovation: The moderating role of firm ownership, Academy of Management Journal, 60(3), 1164-1188. https://doi.org/10.5 465/amj.2015.0230 
Lokshin, B., Belderbos, R., \& Carree, M. (2008). The productivity effects of internal and external RandD: evidence from a dynamic panel data model, Oxford Bulletin of Economics and Statistics, 70(3), 399-413. https://doi.org/10.1111/j.14680084.2008.00503.x

Lukas, B. A., \& Ferrell, O. C. 2000. The effect of market orientation on product innovation, Journal of the Academy of Marketing Science, 28(2), 239-247. https://doi.org/10.1177/0092070300282005

Martinez-Noya, A., Garcia-Canal, E., \& Guillen, M. F. (2012). International R\&D service outsourcing by technologyintensive firms: whether and where? Journal of International Management, 18(1), 18-37. https://doi.org/10.1016/j.intman.2011.06.004

Mateut, S. (2018). Subsidies, financial constraints and firm innovative activities in emerging economies, Small Business Economics, 50(1), 131-162. https://doi.org/10.1007/s11187-017-9877-3

Menon, T., \& Pfeffer, J. (2003). Valuing internal vs. external knowledge: Explaining the preference for outsiders, Management Science, 49(4), 497-513. https://doi.org/10.1287/mnsc.49.4.497.14422

Migdadi, M. M., Zaid, M. K. A., Yousif, M., Almestarihi, R. D., \& Al-Hyari, K. (2017). An Empirical Examination of Knowledge Management Processes and Market Orientation, Innovation Capability, and Organisational Performance: Insights from Jordan, Journal of Information \& Knowledge Management, 16(1), 1750002-1-32. https://doi.org/10.1142/S0219649217500022

Monferrer, D., Blesa, A., \& Ripolles, M. (2015). Born globals trough knowledge-based dynamic capabilities and network market orientation, BRQ Business Research Quarterly, 18(1), 18-36. https://doi.org/10.1016/j.brq.2014.04.001

Narula, R. (2002). Innovation systems and 'inertia'in RandD location: Norwegian firms and the role of systemic lock-in, Research Policy, 31(5), 795-816. https://doi.org/10.1016/S0048-7333(01)00148-2

Neupane, R. P., Sharma, K. R., \& Thapa, G. B. (2002). Adoption of agroforestry in the hills of Nepal: A logistic regression analysis, Agricultural Systems, 72(3), 177-196. https://doi.org/10.1016/S0308-521X(01)00066-X

Niebuhr, A., \& Peters, C. (2012). Labour diversity and firm's innovation: Evidence from Germany, Nuremburg: IAB Institute for Employment Research.

Ozkaya, H. E., Droge, C., Hult, G. T. M., Calantone, R., \& Ozkaya, E. (2015). Market orientation, knowledge competence, and innovation, International Journal of Research in Marketing, 32(3), 309-318. https://doi.org/10.101 6/j.ijresmar.2014.10.004

Poot, T., Faems, D., \& Vanhaverbeke, W. (2014). Toward a dynamic perspective on open innovation: A longitudinal assessment of the adoption of internal and external innovation strategies in the Netherlands, International Journal of Innovation Management, 13(2), 1-24.

Prokop, V., \& Stejskal, J. (2017). Different approaches to managing innovation activities: An analysis of strong, moderate, and modest innovators. Inzinerine Ekonomika-Engineering Economics, 28(1), 47-55. http://dx.doi.org/10.57 55/j01.ee.28.1.16111

Reed, R., Storrud-Barnes, S., \& Jessup, L. (2012). How open innovation affects the drivers of competitive advantage: Trading the benefits of IP creation and ownership for free invention, Management Decision, 50(1), 58-73. https://doi.org/10.1108/00251741211194877

Retherford, R. D., \& Choe, M. K. (2011). Statistical Models for Causal Analysis, New York: John Wiley.

Robin, S., \& Schubert, T. (2013). Cooperation with public research institutions and success in innovation: Evidence from France and Germany, Research Policy, 42(1), 149-166. https://doi.org/10.1016/j.respol.2012.06.002

Santamaría, L., Nieto, M. J., \& Barge-Gil, A. (2009). Beyond formal R\&D: Taking advantage of other sources of innovation in low-and medium-technology industries, Research Policy, 38(3), 507-517. https://doi.org/10.1016/j.re spol.2008.10.004

Schneider, S., \& Spieth, P. (2013). Business model innovation: Towards an integrated future research agenda, International Journal of Innovation Management, 17(1), 1-34. https://doi.org/10.1142/S136391961340001X

Tether, B. S. (2002). Who co-operates for innovation, and why: an empirical analysis, Research Policy, 31(6), 947-967. https://doi.org/10.1016/S0048-7333(01)00172-X

Tsai, W. (2001). Knowledge transfer in intraorganizational networks: Effects of network position and absorptive capacity on business unit innovation and performance, Academy of Management Journal, 44(5), 996-1004. https://doi.org/10.23 $07 / 3069443$

Vaaler, P. M., \& McNamara, G. (2010). Are technology-intensive industries more dynamically competitive? No and yes, Organization Science, 21(1), 271-289. https://doi.org/10.1287/orsc.1080.0392 
Viktor Prokop, Jan Stejskal, Petr Hajek. The Role of Information Sources in Firm R\&D Activities - The Case of German...

van der Duin, P., Heger, T., \& Schlesinger, M. D. (2014). "Toward networked foresight? Exploring the use of futures research in innovation networks, Futures, (59), 62-78. https://doi.org/10.1016/j.futures.2014.01.008

Vega-Jurado, J., Gutierrez-Gracia, A., \& Fernandez-de-Lucio, I. (2009). "Does external knowledge sourcing matter for innovation? Evidence from the Spanish manufacturing industry," Industrial and Corporate Change, 18(4), 637-670. https://doi.org/10.1093/icc/dtp023

Verhees, F. J., \& Meulenberg, M. T. (2004). "Market orientation, innovativeness, product innovation, and performance in small firms," Journal of Small Business Management, 42(2), 134-154. https://doi.org/10.1111/j.1540627X.2004.00102.X

Von Hippel, E. (1986). Lead users: A source of novel product concepts, Management Science, 32(7), $791-805$. https://doi.org/10.1287/mnsc.32.7.791

Von Stamm, B. (2004). Collaboration with other firms and customers: innovation's secret weapon, Strategy and Leadership, 32(3), 16-20. https://doi.org/10.1108/10878510410535727

Weinberg, S. L., \& Abramowitz, S. K. (2002). Data Analysis for the Behavioral Sciences using SPSS, Cambridge: Cambridge University Press.

West, J., \& Bogers, M. (2014). Leveraging external sources of innovation: a review of research on open innovation, Journal of Product Innovation Management, 31(4), 814-831. https://doi.org/10.1111/jpim.12125

West, J., \& Gallagher, S. (2006). Challenges of open innovation: the paradox of firm investment in open-source software, $R \& D$ Management, 36(3), 319-331. https://doi.org/10.1111/j.1467-9310.2006.00436.x

World Economic Forum. The Global Competitiveness Report 2017-2018, [online]. 2017 [cit. 2018-09-06]. Available at: https://www.weforum.org/reports/the-global-competitiveness-report-2017-2018.

Zander, I., \& Solvell, O. (2000). Cross-border innovation in the multinational corporation: A research agenda, International Studies of Management and Organization, 30(2), 44-67. https://doi.org/10.1080/00208825.2000.11656787

Zhou, K. Z., \& Li, C. B. (2012). How knowledge affects radical innovation: Knowledge base, market knowledge acquisition, and internal knowledge sharing, Strategic Management Journal, 33(9), 1090-1102. https://doi.org/10.1002/smj.1959

Zieba, M., Bolisani, E., Paiola, M., \& Scarso, E. (2017). Searching for innovation knowledge: insight into KIBS companies, Knowledge Management Research \& Practice, 15(2), 282-293. https://doi.org/10.1057/s41275-017-0050-1

The article has been reviewed.

Received in June, 2018; accepted in June, 2019. 